Article

\title{
Relationships between Law Enforcement Authorities and Drone Journalists in Spain
}

\author{
Jorge Gallardo-Camacho ${ }^{1, *}$ and Vanessa Rodríguez Breijo ${ }^{2}$ \\ ${ }^{1}$ Department of Communication, Camilo José Cela University, 28692 Madrid, Spain; E-Mail: jgallardo@ucjc.edu \\ 2 Department of Communication Sciences and Social Work, University of La Laguna, 38320 Tenerife, Spain; \\ E-Mail: vrbreijo@ull.edu.es \\ * Corresponding author
}

Submitted: 31 March 2020 | Accepted: 25 May 2020 | Published: 27 July 2020

\begin{abstract}
The article analyzes the relationship between law enforcement authorities and drone journalists, professionals who use unmanned aerial vehicles (UAVs) for newsgathering purposes, in Spain. The study has two specific objectives. First, to identify the criteria that law enforcement authorities have set for the public dissemination in traditional and social media of the drone footage they have obtained as part of their police operations, and to characterize the relationship that exists between law enforcement authorities and drone journalists. The study is guided by three hypotheses: Spanish law enforcement authorities have more capacity than journalists to shoot aerial news footage (H1); for Spanish law enforcement authorities, the informational use that can be made of the drone footage they obtain is of secondary importance (H2); and drone journalists feel their work is heavily restricted by law enforcement authorities (H3). These hypotheses are tested with the use of in-depth interviews with representatives of three law enforcement organizations in Spain and five drone pilots who have collaborated with news media outlets. The study concludes that the current regulatory framework for UAVs in Spain is very restrictive, in comparison to other countries, which prevents the development of drone journalism.
\end{abstract}

\section{Keywords}

aerial footage; drones; journalism; news production; television; unmanned aerial vehicles

\section{Issue}

This article is part of the issue "Journalism from Above: Drones, the Media, and the Transformation of Journalistic Practice" edited by Jonas Harvard (Mid Sweden University, Sweden), Mats Hyvönen (Uppsala University, Sweden) and Ingela Wadbring (Mid Sweden University, Sweden).

(C) 2020 by the authors; licensee Cogitatio (Lisbon, Portugal). This article is licensed under a Creative Commons Attribution 4.0 International License (CC BY).

\section{Introduction}

Drones, also known as unmanned aerial vehicles (UAVs), are remotely guided aircraft that can carry highresolution video cameras that work at high altitudes and distances (Brasil \& Moratti Frazão, 2014). The first uses of UAVs for journalistic purposes date back to 2010, when a paparazzi used a drone to take aerial pictures of Paris Hilton on the French Riviera. Then in 2011, the Daily (a former iPad-only news app) and CNN used drones to capture the damage caused by a tornado (Cruz Silva, 2014). Since then, drone journalism has rapidly spread around the world (Şahin, 2018).
Drones have many advantages over manned aircraft, like airplanes and helicopters, when it comes to capturing aerial footage. The first advantage is their lower cost. Drones can also improve the quality of videos and photos, thanks to the miniaturization of imagecapturing technology (Mazur, Wiśniewski, \& McMillan, 2016). Another benefit for journalists is that drones provide a range of perspectives that other forms of photography do not allow (Belair-Gagnon, Owen, \& Holton, 2017). UAVs are also an attractive option for the live coverage of man-made and natural disasters, and for filming hardto-reach and dangerous areas, such as war zones and flooded areas (Mademlis et al., 2019). 
The drone industry in Spain consists mostly of small businesses and freelancers (93\% of the total), whose scope is mainly regional. Moreover, $75 \%$ of drone operators have been on the market for less than 3 years. In terms of turnover, $78 \%$ of them earn less than $€ 50,000$ per year, and only $2.4 \%$ exceeds $€ 5$ million. It is a small niche of providers who operate low-cost, yet professional, equipment and offer basic services, most of them audiovisual (46\% of the total), so it is difficult for them to carry out large-scale projects (ToDrone, 2016).

Large television companies in Spain do not have their own drones (Fernández Barrero, 2018), and buy footage from aerial cinematographers or news agencies whenever they need it. They also use material produced and shared, free of charge, by institutions and organizations, such as the army, NGOs, and police departments. Private television companies sometimes commission the filming of aerial footage but at very low fees which, according to drone pilots, are not enough to make a living out of this profession. In 2016, natural disaster footage represented $72 \%$ of all the images shoot by drones and broadcast in news programs in Spain (Gallardo-Camacho \& Lavín, 2016).

Increased use of drones has raised significant public safety concerns, as drones can collide and cause injuries or interfere with aircraft. Their use near dangerous places, such as burning buildings and flooded cities, can hinder rescue operations. Not to mention the risk of UAVs being hacked or hijacked (Alwateer, Loke, \& Zuchowicz, 2019). In addition, camera-equipped drones can potentially violate their right to privacy of the people they photograph (McIntyre, 2015).

In Norway and Sweden, Gynnild (2014) found that another problem with the use of drone footage for journalistic purposes has to do with errors in the selection, collection, editing, contextualization and dissemination of videos. As Gynnild (2014) points out, these errors are caused by the fact that a large part of drone footage is not produced by professional journalists nor filmed in the country where it is shown. Drone footage is in fact created and contextualized in other parts of the world by secondary sources, such as news agencies, citizens or government institutions. This is particularly worrying in the case of surveillance images, whose dissemination has increased markedly due to the growing fear of crime and terrorism, when they are presented without disclosing the way data were collected and when they are recontextualized by people who are unaware of their real origin and do not apply journalistic criteria.

Commercial drone operations are permitted in many countries but are often strictly regulated, while regulations for recreational drone flights are more permissive. Aviation authorities around the world often require drone pilots to obtain a license, certificate or permit, and most countries classify drone flights according to the capabilities of the unmanned aircraft. Careless or reckless drone operations face civil or criminal punishments in almost any jurisdiction. Another trend among interna- tional regulations is to require pilots to assess their operations through a certification or permit. Drone regulations are relatively permissive in Europe, Canada, the Middle East, South America and South Pacific countries, while the early stages of drone regulation in the United States of America and Asia have been characterized by some resistance (Ravich, 2016). Drone liability insurance, for bodily injury or property damage, is mandatory in Canada, China, Germany, Poland, the United Kingdom and other countries (Mazur et al., 2016).

The use of drones in Spain was regulated from 2014 to 2017 by the Royal Decree 552/2014, which established that drones weighing less than two kilograms could only fly over unpopulated areas and below 122 meters (Gallardo-Camacho \& Lavín, 2016). The Royal Decree $1036 / 2017$, which defined the new regulatory framework for drones in Spain, allows drone flights over urban areas, crowds, and in non-controlled airspace, provided they are within the visual line of sight, have a maximum takeoff weight lower than 10 kilograms, and keep a 50-meter horizontal distance from buildings or people (Ministry of Interior, 2017). To fly a drone, it is essential to request authorization from the National Aviation Safety Agency (Agencia Estatal de Seguridad Aérea) and to demonstrate that the drone will be operated in 'standard scenarios,' through an aeronautic safety assessment. Otherwise, drone pilots must undertake this assessment using standardized methods and submit it together with the application and the rest of the documentation (National Aviation Safety Agency, 2020).

In the United States of America, the Federal Aviation Administration initially defined drone journalism as an illegal operation on the grounds that it had a commercial purpose. This regulation led to actions and investigations against those who used UAVs to take aerial photographs and video for newsgathering. For this reason, unmanned aircraft were not widely used by media professionals, who strongly criticized this legislation (Holton, Lawson, \& Love, 2015). Meanwhile, the ethics of drone journalism were discussed outside the newsrooms as it was a practice that developed on the fringes of the law. However, the legal requirements to operate UAVs were relaxed in 2016. The current regulation allows small unmanned aircraft to fly, even over people and in restricted airspace (Belair-Gagnon et al., 2017).

European countries at the top of the World Press Freedom Index, such as Finland, Norway, Denmark, The Netherlands and Sweden, as well as Australia, have set regulations that allow the development of drone journalism without excessive restrictions, but also without neglecting security and privacy issues. In contrast, countries at the bottom of this index-compiled by Reporters Without Borders (2019) - apply severe limitations. In Cambodia, Kenya and Nepal, bans on drone flights were enacted and flying restrictions were tightened after individuals made illegal use of drones or disclosed materials the government did not want the public to see. In Thailand, drone operators must ask permis- 
sion directly from the Minister of Transport before flying. The United Arab Emirates have banned the use of drones in Abu Dhabi. In South Africa, the legal ban on drones is complete, although the government cannot efficiently monitor compliance with this regulation. This context seems to indicate that there is a correlation between the general state of freedom of expression in a country and the extent of restrictions set to drone journalism on such a country (Lauk, Uskali, Kuutti, \& Hirvinen, 2016).

As from July 2020, a common regulatory framework came into force in the EU to create an Unmanned Traffic Management System, called the U-Space. In this new framework, drone operations are classified into three types depending on the level of risk involved: open, specific and certified (for low, medium or high risk, respectively), adopting a different regulatory approach for each category. Standardized risk assessments will only be required for medium-and high-risk categories. National aviation authorities shall ensure compliance with EU legislation and the registration and authorization of aircraft (Drone Rules, 2020).

There is consensus on the scarcity of research on drone journalism, because it is a very recent activity (Adams, 2018; Fernández Barrero, 2018; Mclntyre, 2015) and because most studies have focused on the legal and ethical implications of UAV in general (Belair-Gagnon et al., 2017; Hebbel-Seeger, Horky, \& Theobalt, 2017) instead of their journalistic applications.

However, there are some research works that address drone journalism from different perspectives: its ethical considerations (Bartzen Culver, 2014); the implications and awareness of privacy regulations in the use of drones for newsgathering purposes (Finn \& Wright, 2016; McIntyre, 2015); the journalistic features of the stories made with UAVs (Adams, 2018; Şahin, 2018); the ethical principles of journalists who used UAVs despite bans in the United States of America and their role as disruptive innovators (Belair-Gagnon et al., 2017), and expectations and experiences in relation to the use of drones in sporting events (Hebbel-Seeger et al., 2017). In case of Spain, the studies of Gallardo-Camacho and Lavín (2016) and Fernández Barrero (2018) have examined the situation of the use of drones in journalism.

Some of the research carried out around the world on journalists' relationship with law enforcement authorities has allowed us to approach this subject matter in the Spanish context in this article. Tremayne and Clark (2014) focused on the capacity of synoptic surveillance of UAVs operated by private citizens and journalists who hold political or economic power. After analyzing eight cases of drone journalism, they concluded that most of them fulfilled this function, managing to reverse the "panoptic gaze' traditionally exerted from the authorities and corporations towards people.

Bakir (2015) also examined the problem of surveillance of citizens by government and journalists' efforts to counteract and oppose it. Although he does not address this issue from the perspective of drone journalism, he concludes that the way to achieve a balance in power relations is to enhance mutual watching and surveillance. Brucato (2015), for his part, has also confirmed that surveillance of the government by the press increases the information the government institutions provide on a voluntary basis. His study, however, found that police violence has not undergone significant changes, despite the possibility of being always watched by ubiquitous surveillance cameras and new technologies.

Finn and Wright (2016) interviewed civil aviation and data protection authorities in Europe and concluded that they are mostly suspicious of commercial and private drone operators as they are thought to be associated with significant privacy, data protection and ethical risks. In contrast, Feeney (2016) highlights the threat that law enforcement drones pose to the privacy of citizens and the lack of law reforms to address this problem.

Finally, Gynnild (2016) has shed light on one of the factors she identifies as responsible for the lack of alignment between drone journalism and journalistic and transparency ideals: the use of drone footage filmed by government and not by journalists themselves. According to the author, this fact increases the chances of news decontextualization and disconnection between graphic and textual materials.

So far, there are no studies on the relationship between people who use drones for newsgathering and the Security Forces and Corps, which in addition to being responsible for enforcing the law, are UAV operators and provide aerial footage to the media. For this reason, this article aims to develop a better understanding of some of the characteristics of this relationship in Spain.

In Spain, law enforcement is carried out by numerous civilian and military organizations. The civilian category includes the National Police (Policía Nacional/Cuerpo Nacional de Policía); autonomous police forces, under the rule of the regional governments, like the Catalan Police (Mossos d'Esquadra), the Basque Police (Ertzaintza) and the Navarrese Chartered Police (Policía Foral); and the local police forces of each municipality. The military law enforcement authorities include the Civil Guard (Guardia Civil), at the national level, and the port, customs and forest surveillance services. Their objective is to maintain public safety at all these levels of action.

The first specific objective of this research is to address the role of the main Security Forces and Corps as producers of drone footage, which is used by the media for news making. In other words, the objective is to analyze this transfer of material from one law-enforcement organization to an institution responsible for informing the public.

The second specific objective is to explore the relationship between drone pilots who provide aerial footage to news media outlets and the Security Forces and Corps, as law enforcement institutions, more than two years after the new regulation came into force. We investigated drone journalists' perception of freedom 
and repression, the prohibitions or sanctions they have received, their opinion on the status of the Spanish legislation in comparison to that in other countries, and the specialized training they received to work in television.

\section{Hypotheses and Methods}

This research is guided by the following three hypotheses:

H1: In Spain, the Security Forces and Corps have a greater capacity than the media to obtain aerial news footage, because they have their own drones for surveillance and crime investigation and because they have fewer flight restrictions.

$\mathrm{H} 2$ : The main function of the footage obtained by the Security Forces and Corps through drones is to ensure the safety of citizens, while its informative function is secondary. They distribute the footage only after it has fulfilled its main function.

H3: Interviewed drone pilots who provide news footage to news media outlets believe this activity faces many restrictions: they consider the requirements to be excessive and the administrative waiting times too long to be able to cover breaking news events.

To test these hypotheses, we have used a qualitative approach and an exploratory, descriptive research design. A structured interview applied to two expert panels. One composed of the communications officers of the National Police, the Civil Guard and the Catalan Police, and another made up of drone journalists who provide aerial news footage to news media outlets. Tables 1 and 2 show the composition of the panels.

This study ruled out the inclusion of representatives of port, customs and forest surveillance services, as they do not have a direct link to the research questions. Also excluded from the study were experts from the local police departments because their authority in security matters is lower than that of their regional and national counterparts. As for the inclusion of the regional autonomous police forces, it was not possible to obtain a response from the Basque Police and the Navarrese Chartered Police, due to the current national emergency caused by the coronavirus pandemic outbreak. We consider that the responses provided by the representatives of the national armed organizations are the most relevant to the objectives of this study, as they operate the largest number of drones and cover the broadest capacities in the field of security.

As for the second expert panel, it consists of five drone videographers who produce or have produced news footage for media companies. One of them belongs to the Spanish Association of Drones and Similar Devices, while three belong to other companies that provide aerial filming and photography services (Drone Madrid and GoDrone) or connect UAV pilots with potential customers (The Drones Post); and a journalist who owns two drones and works for El Mundo, a national newspaper. This last participant was included to complement the panel with a more particular vision.

The questions asked to the first panel investigated the number of drones owned by their institutions, the news footage production process, the selection and transfer of that material to the media and the publica-

Table 1. Panel of experts representing the Security Forces and Corps.

\begin{tabular}{lllll}
\hline Participants & Affiliation & Position/department & Interview date & Interview type \\
\hline Antonio Nevado Raja & National Police & Head of Press and Media Relations Office & 10 March 2020 & Email \\
Fernando Cubillo & Civil Guard & Head of Information and PR Office & 7 March 2020 & Email and Phone \\
& & & 11 March 2020 &
\end{tabular}

Jordi Peña Camí Catalan Police Communications Office representative 10 March $2020 \quad$ Phone and email

Table 2. Panel of experts representing drone journalists who provide aerial news footage to the media.

\begin{tabular}{lllll}
\hline Participants & Affiliation & Position & Interview date & Interview type \\
\hline Salvador Bellver Escrihuela & $\begin{array}{l}\text { Spanish Association } \\
\text { of Drones and Similar } \\
\text { Devices }\end{array}$ & President & 11 March 2020 & Email \\
César González Galindo & GoDrone & Technical Director & 9 March 2020 & Email \\
Roger Persiva & The Drones Post & Founder & 10 March 2020 & Phone and email \\
Ignacio Espinoza & Drone Madrid & Founding CEO & 12 March 2020 & Email \\
Álvaro Undabarrena Infante & El Mundo & Reporter, drone-owner & 3 July 2020 & Phone and email
\end{tabular}


tion of this material on the institution's social networks, the characteristics of their relationship with journalists and the specific training of their UAVs operators. In the second panel we were interested in knowing how free or restricted drone pilots feel they are to carry out their profession, their perception of the new regulations in comparison to the regulations in other countries, their experience with the Security Forces and Corps while using drones to obtain aerial footage for journalistic purposes, their contractual relationship with the media and their specialized training to work in television.

Once the answers were obtained from the expert panels, they were systematized in a comparative table that was used as a reference to test the hypotheses and answer the research questions, using a qualitative, exploratory-descriptive design, with no statistical representativeness.

\section{Results}

\subsection{Aerial Footage Filmed by the Security Forces and Corps}

The question about the number of drones owned by the Civil Guard was answered only by Fernando Cubillo, Lieutenant Colonel and head of the Head of Media and Social Relations of the Civil Guard. He stated that they own 60 drones. The communications officers of the National Police and the Catalan Police stated that their institutions cannot disclose that figure, for security reasons.

Jordi Peña Camí, the representative of the Communications Office of the Catalan Police, explained that this institution uses drones for the purposes of citizen safety, mainly for police investigation. He remarks that if a case is under secrecy in summary proceedings, they do not distribute drone footage about it. In cases like the Mobile World Congress or air and rail accidents, he narrates, the Catalan Police offers the media images captured by the security devices to show how their agents are working in those areas.

Cubillo (Civil Guard), for his part, explains that the Civil Guard uses drones to capture audiovisual evidence of crimes and administrative misconduct, not to provide the media with these materials. He mentions that UAVs belong to the Research Units, not to the communication offices. Once the images are authorized by the competent judicial body, they are offered to the Information and Public Relations Office for release.

Public dissemination of drone footage through the media and social networks occurs in the three law enforcement institutions. Peña Camí (Catalan Police) adds that the footage they distribute to the media are also published on their social networks and vice versa, with the aim of publicizing the work of the Catalan Police.

Antonio Nevado Raja, Head of the Press and Media Relations Office of the National Police, explains that they send footage to all accredited news media outlets on their distribution lists. Prior to this, "they assess the suitability of the distribution of the footage, edit it to cut out restricted information or images, and distribute it with the relevant press release." Peña Camí (Catalan Police) claims that the Catalan Police also sends the information to all media outlets.

With regard to the most frequent themes of the images, Peña Camí (Catalan Police) mentions that the footage filmed by the Catalan Police is about "investigations in which there is no classified information, issues of citizen safety, rail or air accidents, etc." Meanwhile, according to Nevado Raja (National Police), the footage shot by the National Police refers to "concluded police operations." The Civil Guard provided no answers to this question.

The three organizations acknowledged, through their communication officers, that they have agents with formal education and authorization to fly UAVs but did not reveal the number of agents.

\subsection{Relationship between Drone Pilots and the Security Forces and Corps}

As for the relationship between the Security Forces and Corps and drone journalists, Peña Camí (Catalan Police) explained that they have to comply with the same regulations as any professional drone-operating company:

Specific authorizations by the National Aviation Safety Agency are required in certain areas, in outdoor locations you have to notify the Interior department 10 days in advance; if it is a space near an airport, more air permits are needed, and the documentation of pilots and drones (insurance, medical certificates, etc.) must be in order.

Journalists cannot fly drones over rail accidents, even if they are not on a restricted area, simply because a police investigation is underway. Moreover, drone filming can be banned for security reasons, as it happened during the Carnival of Sitges.

Neither the National Police nor the Civil Guard make distinctions in their treatment of journalists. Nevado Raja (National Police) explains that the Police acts when a drone flies over areas restricted by security reasons, regardless of who the drone operator is. He remarks that the use of drones can never violate people's privacy and security.

None of the institutions has developed a manual to guide their relationships with media regarding the use of drones. Violations committed by those who work in them, or for them, have not been counted because they do not differentiate between the different persons reported.

When the panel of drone pilots were asked their opinion about the Spanish legislation, those who represent companies that provide audiovisual services, or serve as link for this activity, and Alvaro Undabarrena Infante, re- 
porter of El Mundo, agree to describe it as very restrictive. Four pilots consider that other countries are more permissive and are more advanced on regulatory issues. The examples they mentioned were the United States of America, France and Germany. Roger Persiva, founder of The Drones Post, mentions that in the latter two countries, it is up to municipalities to decide whether to authorize or deny permission to fly, making operations easier. For his part, the president of Spanish Association of Drones and Similar Devices, Salvador Bellver Escrihuela, rightly points out that the regulatory framework is more restrictive in some countries and more permissive in others, and that it is necessary to achieve a balance between safety and operability.

César González Galindo, technical director of GoDrone, explains that the regulatory framework establishes a series of requirements and encompasses all operations in general, without specific guidelines for the media. He warns that "drones cannot fly over urban areas, cannot fly over people, cannot fly within $8 \mathrm{~km}$ of any airport or $12 \mathrm{~km}$ if it is instrumental, and cannot fly at night." He then reconsiders:

You could apply for special permits to fly in restricted areas, but these procedures are painstaking and the authority can take up to six months to reply to your permit application; if you do not receive a response within this period, administrative silence is taken as a denial of the request.

It concludes that it is difficult to do aerial drone filming events under these circumstances.

Ignacio Espinoza, the founder of Drone Madrid, also provides details of the restrictions set by the legislation: "The Ministry of Defense restricts the publication of footage filmed in restricted zones, for security reasons, or because it is vulnerable content." Persiva (The Drones Post) recognizes that the new regulation opens the door to flying and filming in areas that were previously prohibited, such as urban environments and areas close to airports, but with many conditions. He explains that "permits must be requested, security assessments must be carried out, we have to wait for the administration's response, and ultimately hope the police or the Civil Guard do not have any impediment." For this drone pilot, this procedure makes it very difficult to use a drone for the coverage of breaking news. He concludes: "Sometimes permits must be processed and the administration's response can take several months."

Undabarrena Infante (EI Mundo) summarizes his opinion in the following way: "Currently everything is forbidden except for exceptional cases, those that do not violate the privacy of others, that is, you can only film monuments and things like that." To film sporting events drone pilots must request authorization from the National Aviation Safety Agency, which is very complicated. According to him:
The regulations that have been passed so far in Spain have not solved the needs of journalists. The regulatory framework in Spain has made drone pilots and operators feel that every drone flight they perform is in violation of the law.

With this view of the Spanish law, it is not surprising that three of the drone pilots would respond that they do not feel free when performing unmanned flights for journalistic purposes. González Galindo (GoDrone) explains that "depending on the incident, it is better to refrain from flying drones, unless the Security Forces and Corps themselves ask for your help, to avoid hindering their work." Persiva (The Drones Post) considers that "with the law in hand, in the event of an incident, even if it occurred in a free-flight area, it could not be done." He remarks that "if there are emergency and police teams in the area, they would surely prohibit drone flights." Undabarrena Infante (EI Mundo) acknowledges that he has done aerial filming, "but never in Madrid, because it is risking more than you should." He considers that one way to be able to publish his videos is to upload them to YouTube and share the link in an article of the newspaper where he works, "but never as a journalist, always as a citizen."

Espinoza (Drone Madrid) did not answer the question but sent a link to the ENAIRE initiative of the Ministry of Transport, Mobility and Urban Agenda (2020), which has an extraordinary procedure to fly a drone in situations of risk, catastrophe or public calamity, subject to the request of the public authority responsible for managing such situations. However, the pilot did not offer further comment on it. Bellver Escrihuela (Spanish Association of Drones and Similar Devices) is the only pilot on the panel who stated that he does feel free and considers that there is no problem if drone users comply with the regulations.

None of the pilots on the panel reported a bad relationship with the Security Forces and Corps in this study. Even Bellver Escrihuela (Spanish Association of Drones and Similar Devices) describes their relationship as "very good," adding that "professional drone pilots are aware of their limitations and the penalties they are exposed to." In the same line, González Galindo (GoDrone) and Persiva (The Drones Post) believe that there are no problems when drone operators comply with the regulations. Espinoza (Drone Madrid) points out that some agents lack information, but drone operations are gradually becoming standardized. However, Persiva (The Drones Post) remembers that once the police prevented him from taking aerial news footage of an event that took in an isolated mountain site. He concludes that "despite no authorization was requested from the National Aviation Safety Agency, police officers can, at any given time, decree that you cannot fly a drone over an area where police intervention is taking place."

Tables 3 and 4 summarize the responses obtained from the expert panels. 
Table 3. Summary of answers provided by the panel of experts representing the Security Forces and Corps.

\begin{tabular}{|c|c|c|c|}
\hline Questions & $\begin{array}{l}\text { Jordi Peña Camí } \\
\text { Catalan Police }\end{array}$ & $\begin{array}{l}\text { Antonio Nevado Raja } \\
\text { National Police }\end{array}$ & $\begin{array}{l}\text { Fernando Cubillo } \\
\text { Civil Guard }\end{array}$ \\
\hline $\begin{array}{l}\text { How many drones does } \\
\text { your institution own? How } \\
\text { many of them are used to } \\
\text { generate news content for } \\
\text { audiovisual media? }\end{array}$ & $\begin{array}{l}\text { We cannot disclose the } \\
\text { number of drones at our } \\
\text { disposal. Sometimes our } \\
\text { operations are filmed to } \\
\text { show the media how we } \\
\text { work. }\end{array}$ & $\begin{array}{l}\text { We cannot disclose the } \\
\text { number of drones at our } \\
\text { disposal. }\end{array}$ & $\begin{array}{l}60 \text { drones. They belong to } \\
\text { the Research Units, not the } \\
\text { communications offices. }\end{array}$ \\
\hline $\begin{array}{l}\text { Do you have a manual to } \\
\text { guide relationships } \\
\text { between law enforcement } \\
\text { authorities and the media } \\
\text { regarding drone use? }\end{array}$ & $\begin{array}{l}\text { No. The communication } \\
\text { area serves as link between } \\
\text { journalists and police } \\
\text { authorities. }\end{array}$ & We do not know. & No. \\
\hline $\begin{array}{l}\text { Do journalists feel free to } \\
\text { cover news events with } \\
\text { drone filmography? }\end{array}$ & $\begin{array}{l}\text { There are restrictions, so } \\
\text { they cannot be used freely. }\end{array}$ & $\begin{array}{l}\text { We do not know what } \\
\text { journalists think in general. }\end{array}$ & (Did not answer). \\
\hline $\begin{array}{l}\text { How many journalists or } \\
\text { freelancers hired by media } \\
\text { companies have been } \\
\text { fined? }\end{array}$ & $\begin{array}{l}\text { We do not have these data. } \\
\text { When a pilot is fined, we do } \\
\text { not differentiate between } \\
\text { journalists and } \\
\text { non-journalists. }\end{array}$ & No. & No. \\
\hline $\begin{array}{l}\text { Does your organization } \\
\text { have properly trained drone } \\
\text { operators? }\end{array}$ & Yes. & Yes. & Yes. \\
\hline
\end{tabular}

None of the drone pilots in the panel is dedicated exclusively to the production of news footage for the media. They use their UAVs for several activities, not just audiovisual filming. However, three of them (the representatives of GoDrone, Drone Madrid and The Drones Post) claimed to have specific training to work in television. According to the GoDrone's representative, in most cases there is no economic benefit in offering their videos to the media, because they only "include your logo or mention your name in the broadcast news report."

\section{Discussion and Conclusions}

The National Police and the Catalan Police did not disclose the number of drones they own. However, the number revealed by the Civil Guard (60 UAVs) is much higher to than the number revealed by the Spanish media, who outsource the production of aerial images to individuals or small companies, which in turn have a much lower capacity for newsgathering than the aforementioned Security Forces and Corps. The interviews have shown that the National Police and the Civil Guard have trained and accredited drone pilots and can fly over areas where there are ongoing operations (unlike the media), which confirms the first hypothesis (H1) of this exploratory and descriptive study, which proposed that these law enforcement organizations have greater capacity to obtain aerial news footage than the media.

However, the interviews have also shown that the main use of the footage shot by the drones owned by the National Police, the Civil Guard and the Catalan Police is not public dissemination, which also seems confirms the second hypothesis $(\mathrm{H} 2)$. These unmanned aircraft are primarily used to ensure safety, collect evidence and conduct investigations. Only when these police operations are not under secrecy in summary proceedings, the Security Forces and Corps shares the images to the media and disseminates them through their social networks. They are mainly videos of accidents or completed police operations. Before their public dissemination, these videos are edited to highlight the way the organization works (as in the case of the Catalan Police).

Therefore, while these audiovisual materials are useful to inform about events that the media cannot cover due to the legal restrictions, their source is not necessarily always independent and impartial and their production is not necessarily governed by journalistic criteria, which means that they may be edited with certain bias. In media theory, there is some consensus on the role of journalists as guardians of the public interest, to hold those in political and economic power accountable for their possible mistakes (Lashmar, 2017), controlling their 
Table 4. Summary of answers provided by the panel of experts representing drone pilots working for the media.

\begin{tabular}{|c|c|c|c|c|c|}
\hline Questions & $\begin{array}{c}\text { César González } \\
\text { Galindo } \\
\text { (GoDrone) }\end{array}$ & $\begin{array}{c}\text { Roger Persiva } \\
\text { (The Drones Post) }\end{array}$ & $\begin{array}{c}\text { Álvaro } \\
\text { Undabarrena } \\
\text { Infante } \\
\text { (El Mundo) }\end{array}$ & $\begin{array}{l}\text { Ignacio Espinoza } \\
\text { (Drone Madrid) }\end{array}$ & $\begin{array}{c}\text { Salvador Bellver } \\
\text { Escrihuela } \\
\text { (Spanish } \\
\text { Association of } \\
\text { Drones and Similar } \\
\text { Devices) }\end{array}$ \\
\hline $\begin{array}{l}\text { How is your } \\
\text { relationship with } \\
\text { the Security } \\
\text { Forces and } \\
\text { Corps? }\end{array}$ & $\begin{array}{l}\text { It is good, } \\
\text { provided the } \\
\text { regulations are } \\
\text { complied with. }\end{array}$ & $\begin{array}{l}\text { It is good, if you } \\
\text { have fly permits, } \\
\text { although they } \\
\text { are useless if } \\
\text { there is an } \\
\text { ongoing police } \\
\text { investigation. }\end{array}$ & $\begin{array}{l}\text { For news outlets, } \\
\text { it is very } \\
\text { complicated to } \\
\text { avoid being } \\
\text { fined. }\end{array}$ & $\begin{array}{l}\text { Some agents lack } \\
\text { information, but } \\
\text { drone use is } \\
\text { gradually } \\
\text { becoming } \\
\text { regularized and } \\
\text { standardized. }\end{array}$ & $\begin{array}{l}\text { It is very good, as } \\
\text { pilots already } \\
\text { know the legal } \\
\text { restrictions. }\end{array}$ \\
\hline $\begin{array}{l}\text { What is the } \\
\text { difference } \\
\text { between drone } \\
\text { regulations in } \\
\text { Spain and in } \\
\text { other countries? }\end{array}$ & $\begin{array}{l}\text { In Spain it is very } \\
\text { restrictive in } \\
\text { many respects. } \\
\text { Countries like the } \\
\text { United States of } \\
\text { America, France } \\
\text { and Germany are } \\
\text { way ahead. }\end{array}$ & $\begin{array}{l}\text { Our regulations } \\
\text { make us feel we } \\
\text { break the law on } \\
\text { every flight. In } \\
\text { France and } \\
\text { Germany, } \\
\text { municipalities } \\
\text { have the power } \\
\text { to issue fly } \\
\text { permits. }\end{array}$ & $\begin{array}{l}\text { Our regulations } \\
\text { do not allow us } \\
\text { to film virtually } \\
\text { anything, except } \\
\text { for monuments. } \\
\text { Drone use in } \\
\text { sporting events is } \\
\text { very } \\
\text { complicated. }\end{array}$ & $\begin{array}{l}\text { In Spain, it is } \\
\text { more restrictive. } \\
\text { Other countries } \\
\text { are already more } \\
\text { permissive in } \\
\text { challenging } \\
\text { environments. }\end{array}$ & $\begin{array}{l}\text { Restrictions vary } \\
\text { across countries. } \\
\text { We must find a } \\
\text { balance between } \\
\text { safety and } \\
\text { operability. }\end{array}$ \\
\hline $\begin{array}{l}\text { Do you feel you } \\
\text { are free to cover } \\
\text { news events with } \\
\text { drone } \\
\text { filmography? }\end{array}$ & $\begin{array}{l}\text { Not in this type } \\
\text { of situation. } \\
\text { Depending on } \\
\text { the incident in } \\
\text { question, it is } \\
\text { better not to use } \\
\text { drones, unless } \\
\text { the authorities } \\
\text { ask for your } \\
\text { support. }\end{array}$ & $\begin{array}{l}\text { No. With the law } \\
\text { in hand, in the } \\
\text { event of an } \\
\text { incident, even if } \\
\text { it occurred in a } \\
\text { free-flying area, } \\
\text { it cannot be } \\
\text { done. }\end{array}$ & $\begin{array}{l}\text { For the media it } \\
\text { is not convenient } \\
\text { to buy their own } \\
\text { drones. It is } \\
\text { better for them } \\
\text { to use the } \\
\text { footage other } \\
\text { people film for } \\
\text { recreational } \\
\text { purposes. }\end{array}$ & $\begin{array}{l}\text { (Did not answer } \\
\text { but shared a link } \\
\text { to the website of } \\
\text { the ENAIRE } \\
\text { initiative of the } \\
\text { Ministry of } \\
\text { Transport, } \\
\text { Mobility and } \\
\text { Urban Agenda, } \\
\text { 2020). }\end{array}$ & $\begin{array}{l}\text { Yes. We all must } \\
\text { know the } \\
\text { regulations. If we } \\
\text { comply with it, } \\
\text { we will not have } \\
\text { any problems. }\end{array}$ \\
\hline
\end{tabular}

abuses and guaranteeing citizens' right to information (Martínez-Sanz \& Durántez-Stolle, 2019), which is impossible to achieve without investigation and surveillance. However, the circumstances described in this study suggest that it might be difficult for journalists to carry out both activities when the entity under journalistic investigation is the Security Forces and Corps. Although the conducted interviews lack statistical representativeness, the data obtained through them are reminiscent of the findings of Bakir (2015), Brucato (2015) and Mills (2018), who indicate that the 'synoptic' surveillance from journalists and citizens towards power is not balanced against the 'panoptic gaze' that occurs in the opposite direction. In addition, as Gynnild (2016) explains, the use of externally-produced videos could make complicate the contextualization and explanation of the news stories the journalist has investigated, and could increase the risk of the situation described by Diezhandino (2007), in which the media mainly develop an institutional agenda based on government interests, rather than an agenda of their own based on the investigation and inquiries carried out by their own journalists.

Ideally, to take advantage of all the opportunities that UAVs offer to journalism-like bird's eye views of difficult news situations and live surveillance for investigative journalism, to mention just two-journalists should be the ones who use drones for newsgathering or the ones who commission others to do so. According to the drone pilots interviewed for this research, the administrative processing of the requirements established by the legislation should be shortened and streamlined, always within the limits imposed by security and privacy concerns. The expert panel should be expanded in future studies, to determine whether this view can be generalized to all those who use drones for newsgathering.

In Spain, the restrictions applied to the filming of news footage are the same as for any other commercial use of drones. The representatives of the Security Forces and Corps interviewed for this study do not process these requests separately nor consider the speed of 
authorization required to produce news footage. There is no specific manual or regulation for the media. Some of the pilots interviewed mention that it was precisely for these reasons that they do not feel free to use drones for newsgathering, because of the large number of restrictions imposed by the regulations and the Security Forces and Corps during ongoing police operations. These participants also fear the sanctions the authorities may impose on them. Their general perception is that drone legislation is more permissive and flexible in the rest of the world. These results confirm the third hypothesis $(\mathrm{H} 3)$, although the number of interviews conducted for the study does not allow us to generalize the results.

Although the new law expands the types of places where drones can film, it requires drone operators to perform a security assessment when drone filmography is going to be carried out in non-standard scenarios. The waiting times involved in this assessment and the resolution of the administration limit the use of drone cameras to cover breaking news events. This could be the reason why some of the interviewed drone pilots feel the new law imposes even more restrictions on drone journalism and, essentially, only allows the filming of monuments. For the panel of drone pilots, the procedures are complicated and the waiting times for their resolution are too long, as if the limitations set by the previous law remained in force. They perceive the requirements as restrictions because the waiting times of the procedures hinder the immediate coverage of news events.

Authors such as Lauk et al. (2016) and Ravich (2016) have found correlations between regulations on the use of drones for newsgathering and the level of freedom of expression of countries. International regulations range from permissive, as in Nordic nations, to totally restrictive, such as those in Kenya and the United Arab Emirates. In this context, it is necessary to assess whether the restrictions are based only on the dangers that drones pose to security and privacy, or whether are related to the need to prevent the filming and disclosure of videos potentially harmful to the reputation of institutions and individuals in power, or the desire to restrict access to certain types of information. In any case, the relationship between the media and the Security Forces and Corps, according to the panel of drone pilots, is confrontational to some extent, because the enforcement of drone legislation by the latter is perceived as an obstacle in newsgathering.

Therefore, we agree with Ntalakas, Dimoulas, Kalliris, and Veglis (2017), who point out that the great challenge for drone journalism is to advocate for a regulatory framework that offers drone journalists the desired freedom to investigate and inform, without violating ethical, privacy and security implications. However, in Spain there is also an economic motivation. Interviewed drone pilots acknowledge that they do not work exclusively for media companies, because it is not profitable for them. Most of them operate other types of UAVs, despite several of them have journalistic and audiovisual training.
Drone-generated content can be a valuable tool for storytelling, for its profitability and data collection capabilities (Ntalakas et al., 2017). Drone footage provides credibility to news storytelling because of the reality it conveys, which previously required the physical presence of the reporter, and raises awareness about issues, places and events that were previously ignored (Gynnild, 2016). However, the circumstances described in this article seem to constitute obstacles that currently prevent the development of drone journalism in Spain. However, the forthcoming entry into force of the new European legislation, which classifies drone operations according to risk levels, reduces requirements and unifies national regulations, could open new opportunities. It will be useful to study the impact of this new legislation on the development of the newsgathering use of UAVs once its provisions begin to be implemented. Moreover, a study with a wider sample of drone pilots and law enforcement authorities needs to be carried out to be able to generalize the results.

Based on this work, we propose the creation of a green paper to guide relationships between journalists and law enforcement authorities to find a democratic balance between citizen security, investigative journalism and the obtaining of aerial images that expand audiovisual news content. This green paper should enable a specific procedure for the coverage of journalistic events, in which UAV flight requirements are shortened and reduced. One premise for expediting these procedures could be giving local and non-national authorities power to issue drone flight permits, to avoid the accumulation of applications. In any case, the security and privacy criteria, considered in the current legislation, should also include the need to inform citizens and specify under what circumstances the right to information should prevail over drone flight restrictions.

\section{Acknowledgments}

This research has been funded by the Camilo José Cela University through the 6th Call for Research Aid, as part of the project 'Interaction 3.0,' led by Jorge GallardoCamacho.

\section{Conflict of Interests}

The authors declare no conflict of interests.

\section{References}

Adams, C. (2018). Tinker, tailor, soldier, thief: An investigation into the role of drones in journalism. Digital Journalism, 7(5), 658-677.

Alwateer, M., Loke, S. W., \& Zuchowicz, A. M. (2019). Drone services: Issues in drones for location-based services from human-drone interaction to information processing. Journal of Location Based Services, 13, 94-127. 
Bakir, V. (2015). "Veillant panoptic assemblage": Mutual watching and resistance to mass surveillance after Snowden. Media and Communication, 3(3), 12-25.

Bartzen Culver, K. (2014). From battlefield to newsroom: Ethical implications of drone technology in journalism. Journal of Mass Media Ethics, 29, 52-64.

Belair-Gagnon, V., Owen, T., \& Holton, A. E. (2017). Unmanned aerial vehicles and journalistic disruption: Perspectives of early professional adopters. Digital Journalism, 5(10), 1226-1239.

Brasil, A., \& Moratti Frazão, S. (2014). Drones no ar e ninjas nas ruas: Os desafios do jornalismo imersivo nas mídias radicais [Drones on the air and ninjas on the streets: The challenges of immersive journalism in the radical media]. Sessões do Imaginário, 8(30), 127-136.

Brucato, B. (2015). The new transparency: Police violence in the context of ubiquitous surveillance. Media and Communication, 3(3), 39-55.

Cruz Silva, J. A. (2014). Is Ecuador prepared to deploy drone journalism? (Doctoral dissertation). The University of Edinburgh, Edinburgh, UK.

Diezhandino, M. P. (2007). Periodismo en la era de internet [Journalism in the era of Internet]. Barcelona: Ariel.

Drone Rules. (2020). EU regulations update. Drone Rules. Retrieved from https://dronerules.eu/es/ professional/eu_regulations_updates

Feeney, M. (2016). Surveillance takes wing: Privacy in the age of police drones. Policy Analysis, 807, 1-20.

Fernández Barrero, M. A. (2018). Journalism and drones: Challenges and opportunities of the use of drones in news production. Doxa Comunicación, 26, 35-58.

Finn, R. L., \& Wright, D. (2016). Privacy, data protection and ethics for civil drone practice: A survey of industry, regulators and civil society organizations. Computer Law \& Security Review, 32(4), 577-586.

Gallardo-Camacho, J., \& Lavín, E. (2016). Uso de drones con fines informativos en empresas de televisión en España [Use of drones for information purposes in television companies in Spain]. El Profesional de la Información, 25(2), 217-225.

Gynnild, A. (2014). Surveillance videos and visual transparency in journalism. Journalism Studies, 15(4), 449-463.

Gynnild, A. (2016). The robot eye witness. Digital Journalism, 2(3), 334-343.

Hebbel-Seeger, A., Horky, T., \& Theobalt, C. (2017). Usage of drones in sports communication: New aesthetics and enlargement of space. Athens Journal of Sports, 4(2), 89-106.

Holton, A. E., Lawson, S., \& Love, C. (2015). Unmanned aerial vehicles: Opportunities, barriers, and the future of "drone journalism." Journalism Practice, 9(5), 634-650.

Lashmar, P. (2017). No more sources? The impact of Snowden's revelations on journalists and their confidential sources. Journalism Practice, 11(6), 665-688.
Lauk, E., Uskali, T., Kuutti, H., \& Hirvinen, H. (2016). Drone journalism: The newest global test of press freedom. In U. Carlsson (Ed.), Freedom of expression and media in transit (pp. 117-125). Sweden: Nordicom.

Mademlis, I., Mygdalis, V., Nikolaidis, N., Montagnuolo, M., Negro, F., Messina, A., \& Pitas, I. (2019). Highlevel multiple-UAV cinematography tools for covering outdoor events. IEEE Transactions on Broadcasting, 65(3), 627-635.

Martínez-Sanz, R., \& Durántez-Stolle, P. (2019). Performance of investigative journalism in Spain: The perception of its current state. Revista Latina de Comunicación Social, 74, 822-883.

Mazur, M., Wiśniewski, A., \& McMillan, J. (2016). Clarity from above: PwC global report on the commercial applications of drone technology. Poland: PwC Drone Powered Solutions Centre. Retrieved from https:// www.pwc.pl/pl/pdf/clarity-from-above-pwc.pdf

Mclntyre, K. (2015). How current law might apply to drone journalism. Newspaper Research Journal, 36(2), 158-169.

Mills, A. (2018). Now you see me: Now you don't: Journalists' experiences with surveillance. Journalism Practice, 13(6), 690-707.

Ministry of Interior. (2017). Royal Decree 1036/2017, of December 15th, to regulate the civil use of remote controlled aircraft (N.o 316, Sec. I, pp. 129609-129641). Madrid: Ministry of Interior.

Ministry of Transport, Mobility and Urban Agenda. (2020). Drones. Enaire. Retrieved from https://www. enaire.es/servicios/drones

National Aviation Safety Agency. (2020). Drones. National Aviation Safety Agency. Retrieved from https://www.seguridadaerea.gob.es/lang_ castellano/cias_empresas/trabajos/rpas/uso_ profesional/default.aspx

Ntalakas, A., Dimoulas, C., Kalliris, G., \& Veglis, A. (2017). Drone journalism: Generating immersive experiences. Journal of Media Critiques, 3(11), 187-199.

Ravich, T. (2016). A comparative global analysis of drone laws: Best practices and policies. In B. Custers (Ed.), The future of drone use (pp. 301-322). The Hague: T. M. C. Asser Press.

Reporters Without Borders. (2019). World press freedom index. Reporters Without Borders. Retrieved from https://rsf.org/en/ranking

Şahin, M. (2018). Drone Gazeteciliğinin Haber Değerine Katkısı ve Türkiye Pratiği [Turkey's practical value and contribution to drone journalism]. Iletişim Kuram ve Araştırma Dergisi, 2018(47), 262-272.

ToDrone. (2016). 1er barómetro del sector de los drones en España [First survey of the drone sector in Spain]. Madrid: ToDrone. Retrieved from http://www.todrone.com/wp-content/uploads/ pdf/Informe-Barometro-todrone-baja.pdf

Tremayne, M., \& Clark, A. (2014). New perspectives from the sky. Digital Journalism, 2(2), 232-246. 


\section{COGITATIO}

\section{About the Authors}

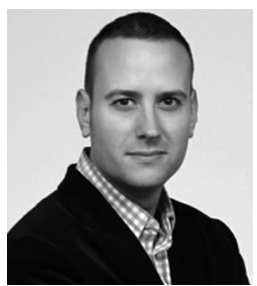

Jorge Gallardo-Camacho is a Professor at the School of Communication and Humanities of the Camilo José Cela University, where he directs the BA program in Communication. He holds a PhD in Communication from the University of Malaga and an MBA in Television Enterprises from the University of Salamanca. He has 15 years of teaching and research experience. His research areas are audiences, social media and new media. He also works as Director of news programming in Antena 3 Noticias (Spain).

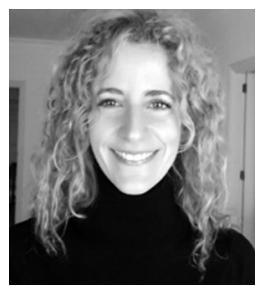

Vanessa Rodríguez Breijo is a Professor at the School of Social Sciences and Communication of the University of La Laguna, where she is also Vice-Dean for Quality. She has nine years of university teaching experience and is accredited as a full-time Professor by the National Agency for Quality Assessment and Accreditation of Spain. Author of two books, 22 journal articles and 21 book chapters. She has participated in 15 international conferences. Winner of the National Award for Excellence in Academic Performance at the Doctoral level in 2011. 